\title{
Plant Development and Harvest Yields of Greenhouse Tomatoes in Six Organic Growing Systems
}

\author{
Janet F.M. Rippy ${ }^{1}$, Mary M. Peet ${ }^{1}$, Frank J. Louws ${ }^{3}$, Paul V. Nelson', \\ David B. Orr ${ }^{1}$, and Kenneth A. Sorensen ${ }^{2}$ \\ North Carolina State University, Raleigh, NC 27695
}

\begin{abstract}
Problems concerning the environmental impact of agriculture have led to a reassessment of the conventional practices used since the 1940s, and a renewed interest by growers in organic farming began during the 1980s. Consumer interest has also increased dramatically, both for health and environmental reasons (Greene, 2000; Lampkin, 1990; Uri, 1999). Since 1996, surveys of natural food wholesalers and retailers indicated that organic produce sales had increased $\approx 20 \%$ yearly (Dimitri and Richman, 2000; Greene, 2001; Greene et al., 2001). Certified organic produce typically commands a higher price than conventionally grown produce. A recent survey of North Carolina-based natural food retailers and wholesalers indicated that buyers were willing to pay up to $25 \%$ more for organically grown vegetables (Estes et al., 1999).
\end{abstract}

As a result of all these factors, an increasing number of growers are considering the use of, or are already employing, organic production methods. Barriers to organic certification are particularly high for greenhouse vegetable growers because virtually no technical information is available. Practices used by an experienced greenhouse organic grower to grow plants in soil have been documented (Grubinger, 1999), but specific practices for injecting fertilizer in the drip irrigation lines were not adequately described. Several grower-formulated mixtures for organic transplant production have been described (Smith, 1994), but there is little or no documentation on how to prepare organic mixes for recirculating hydroponic systems or how to add composts to soilless media used for crop production. Compost teas can be used for drip irrigation in certified organic production. However, in a manual describing the use of compost teas, Ingram and Alms (1999) describe work on compost teas as being in its infancy. The beneficial effects of compost teas were demonstrated, but most testing was conducted by trial and error. This is also true of studies using

Received for publication 9 Sept. 2002. Accepted for publication 12 May 2002. We would like to thank Watson Hall for technical assistance in all aspects of the tomato production, Consuello Arellano and Cavell Brownie for statistical advice, Gil Schoenstein, Ray Sawyer, and Hugh Poole for help in developing organic fertilizer formulas and substrates, and Mike Cherim for advice about pest management. Mention of proprietary products should not be construed as product recommendations or lack thereof.

${ }^{1}$ Dept. of Horticultural Science, Box 7609

${ }^{2}$ Dept. of Entomology, Box 7613

${ }^{3}$ Dept. of Plant Pathology, Box 7616. organic composts as ingredients in potting mixes and in many cases, media and waste characteristics were not reported in detail. In Germany, effluent from a fish farming unit was brought into a hydroponic cucumber ( $\mathrm{CuCu}$ mis sativus L.) and tomato greenhouse as a substitute for some of the normal fertilization (Drews and Rennert, 1992). In this study, the amount of fertilizer added to the hydroponic system was reduced by $16 \%$ for N, $14 \%$ for $\mathrm{P}$, and $12 \%$ for $\mathrm{K}$.

Although a few examples of the successful use of organic materials in greenhouse vegetable production have been documented, it is hard to extrapolate findings to other crops and media. Broiler litter has been tested as a potting component for lettuce (Lactuca sativa L.) (Flynn et al., 1995). There are also examples where system components were well described. Tyler et al. (1993a, 1993b), Kraus et al. (2000), and Kraus and Warren (2000) conducted a series of studies of the effects of composted poultry litter on growth of containerized nursery crops. These studies described the chemical and physical characteristics of litter when combined with a pine bark substrate. However, as nursery crops grow more slowly than tomato crops, their results cannot be directly applied to a greenhouse tomato production system.

Since there are no generally accepted recommendations or guidelines specifically for organic production of greenhouse tomatoes, this study was designed as a systems research project. As such, management practices for each growing season utilized information gathered from the previous growing season(s) to optimize practices for each system. The objectives of this study were to discover methods to produce healthy and productive tomato plants using flowable organic fertilizers, determine formulations for such fertilizers, and develop an organic growing medium that promotes healthy and productive tomato plants. The goal of this research project was to develop a certifiable organic regimen for growing greenhouse tomatoes that would be comparable with those grown conventionally with regard to production methods, as well as nutritional status in leaf tissue, plant development, and harvest yields.

\section{Materials and Methods}

The greenhouse tomato 'Grace' was used in all treatments for all growing seasons. Side-by-side greenhouse compartments were randomly assigned before each growing season to organic (OG) or conventional (CV) methods. There were 32 plants in each greenhouse. Tomato seedlings were transplanted into the greenhouses on 27 Aug. 1998, 14 Jan. 1999, and 4 Nov. 1999 for Fall 1998 (F98), Spring 1999 (S99), and Fall 1999 (F99), respectively.

The greenhouses were $6.1 \mathrm{~m}(20 \mathrm{ft}) \times$ $5.2 \mathrm{~m}(17 \mathrm{ft})\left[31.7 \mathrm{~m}^{2}\right.$ (340 square ft)]. Each was equipped with a Modine gas heater and was vented by a two-speed fan. Cooling was achieved with an evaporative pad system. Cultural management such as staking, pruning suckers, and pollination was similar in each greenhouse. Plants were staked when

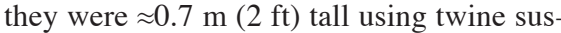
pended from overhead wires. Suckers were pruned on a weekly basis or more if necessary. Plants were pollinated with a mechanical vibrator every day between 11:00 AM and 2:00 PM. Heating, cooling, venting, and fertigation were controlled in each greenhouse with GEM software (Q-Com, Irvine, Calif.). Temperature and relative humidity data were recorded at 15 -min intervals throughout the experiment. The heating/cooling set points were: heat - when daytime temperature was $<24{ }^{\circ} \mathrm{C}$ $\left(75^{\circ} \mathrm{F}\right)$, and when nighttime temperature was $<18{ }^{\circ} \mathrm{C}\left(65^{\circ} \mathrm{F}\right)$; vents - low speed when daytime temperature reached $28^{\circ} \mathrm{C}\left(82^{\circ} \mathrm{F}\right)$ and high speed when daytime temperature reached $31^{\circ} \mathrm{C}\left(87^{\circ} \mathrm{F}\right)$; and cooling pads when daytime temperature reached $33^{\circ} \mathrm{C}\left(92^{\circ} \mathrm{F}\right)$. Plants were fertigated in four cycles daily using $1.89 \mathrm{~L} \cdot \mathrm{h}^{-1}(0.5 \mathrm{gph})$ emitters. They received $0.89 \mathrm{~L} /$ plant $(0.24 \mathrm{gal} /$ plant $)$ daily in Stage 1: transplant to fruit set on the first cluster; $1.2 \mathrm{~L} /$ plant $(0.32 \mathrm{gal} /$ plant $)$ daily in Stage 2: fruit set on the first through fifth clusters, and $1.77 \mathrm{~L} /$ plant (0.47 gal/plant) daily in Stage 3: fruit set on the fifth cluster to the end of the crop (Abbott et al., 1986).

Tomato plants were grown in 18.9-L(5-gal) upright plastic bags, one plant per bag, and arranged in four rows of eight plants each. Two OG fertilizers and two OG substrates were tested during each growing season in a split plot design of media treatments within each fertilizer treatment. The flowable fertilizers and rates were consistent for all three growing seasons. The substrates and amendments varied with each season. Because fertilizers were injected into the irrigation system, specific OG fertilizers were assigned to either the east or west irrigation tube, and could not easily or practically be randomized among plants within the greenhouse. However, they were randomized among seasons. Media treatments were randomized within fertilizer treatments 


\section{Organic substrates and fertilizers}

Organic substrates were tested with various amendments in each growing season. In F98, organic medium 1 (OM1) was 85\% Fafard's Special Organic Mix (Fafard, Anderson, S.C.), a peat/pine bark (P/PB) commercial mix modified to omit the "starter nutrients" and the wetting agent, which are not allowed in organic production, and $15 \%$ by volume Vermicycle (Vermicycle Organics, Charlotte, N.C.) worm compost. Natural Wet (J.H. Biotech, Ventura, Calif.), an organically certified wetting agent, was added to this substrate at a rate of 2 tablespoons/gal, $(1 \mathrm{fl} \mathrm{oz} / \mathrm{gal}$, $\left.7.9 \mathrm{~mL} \cdot \mathrm{L}^{-1}\right)$. OM2 contained a substrate (C/PB) of 63\% Scott's 366 (Scotts, Marysville, Ohio) coconut coir and $22 \%$ composted pine bark to which $15 \%$ Vermicycle worm compost was added. All substrates were amended with dolomitic limestone. An initial nutrient charge was provided from blood meal, $12 \mathrm{~N}-0 \mathrm{P}-0 \mathrm{~K}$; bone meal, $0 \mathrm{~N}-4.84 \mathrm{P}-0 \mathrm{~K}$, and potassium sulfate $\left(\mathrm{K}_{2} \mathrm{SO}_{4}\right), 0 \mathrm{~N}-0 \mathrm{P}-41.5 \mathrm{~K}$. In S99, OM3 and OM4 consisted of the same substrates as OM1 and OM2, respectively but the amendments were reduced. In F99, the OM1 substrate was tested with (OM5) and without (OM6) the addition of Vermicycle. The nutritional amendments were unchanged from S99. However, due to high media $\mathrm{pH}$ in previous growing seasons, dolomitic limestone was omitted for this growing season and elemental sulfur (S) was used instead. OG media treatments and abbreviations are summarized in Table 1 .

Two liquid organic fertilizers were tested. Earth Juice [(EJ), Greenfire, Chico, Calif.] was available in five formulations, termed "Grow," "Bloom," "Catalyst," "Micro-Burst," and "Meta-K." "Grow" has an analysis of $2 \mathrm{~N}-0.44 \mathrm{P}-0.83 \mathrm{~K}$, and is comprised of bat guano, Norwegian sea kelp, natural sulfate of potash, feather meal, oat bran, blood meal, and steamed bone meal. "Bloom" has an analysis of $0 \mathrm{~N}-1.3 \mathrm{P}-0.83 \mathrm{~K}$ and contains bat guano, Chilean seabird guano, Norwegian sea kelp, natural sulfate of potash, steamed bone meal, oat bran, and rock phosphate. "Catalyst" is used to stimulate and enhance microbial activity. It has an analysis of $0.03 \mathrm{~N}-0.0044 \mathrm{P}-0.083 \mathrm{~K}$, and consists of oat bran, kelp, wheat malt, molas- ses, and yeast. "Micro-Burst" supplies $5 \% \mathrm{Mg}$, $0.02 \%$ boron $(\mathrm{B}), 0.05 \%$ copper $(\mathrm{Cu}), 0.2 \%$ iron $(\mathrm{Fe}), 0.1 \%$ manganese $(\mathrm{Mn})$, and $0.15 \%$ zinc $(\mathrm{Zn})$, and is derived from kelp meal, $\mathrm{MgSO}_{4}$, borax, $\mathrm{CuSO}_{4}, \mathrm{FeSO}_{4}, \mathrm{MnSO}_{4}$, and $\mathrm{ZnSO}_{4}$. "Meta-K" contains $10 \% \mathrm{~K}$ from seaweed. The other OG fertilizer was Magna Gro [(MG), Magna Gro,Lawrence, Kans.]. MG is available in several formulations. "Hydroponic Base Mix" has an analysis of $2 \mathrm{~N}-1.3 \mathrm{P}-5 \mathrm{~K}$, and is comprised of poultry compost tea, pasteurized blood meal, calcium phosphate $\left[\mathrm{Ca}\left(\mathrm{H}_{2} \mathrm{PO}_{4}\right)_{2}\right]$, and seaweed. This also contains trace minerals with fermented molasses in the form of $\mathrm{Mg} \mathrm{SO}_{4}$, $\mathrm{Zn} \mathrm{SO}_{4}$, and $\mathrm{Fe} \mathrm{SO}_{4}$. The level of nitrogen (N) was supplemented with $19 \% \mathrm{~N}$ from poultry compost tea and pasteurized blood meal. Levels of $\mathrm{K}$ were supplemented with K-9, which is $7.47 \% \mathrm{~K}$ from seaweed. Organic forms of trace minerals as $6 \% \mathrm{~B}, 6 \% \mathrm{Fe}, 6 \% \mathrm{Mg}$, and $6 \% \mathrm{Ca}$ were also available in MG products.

\section{Conventional substrates and fertilizers}

Tomatoes were grown conventionally in each growing season to represent typical greenhouse production. Fertilization and substrate practices in $\mathrm{CV}$ followed guidelines for "bag culture" of tomatoes as described by Carpenter (1982). For all growing seasons, the conventional growing medium was Southland's SI-1 (Southland, Greensboro, N.C.), a peat/perlite/vermiculite blend containing a "starter" nutrient charge to which composted pine bark was added at a rate of $50 \%$ by volume. For each growing season, the $\mathrm{CV}$ substrate was amended with the same amount of limestone as was added to the organic substrate.

The CV fertilizer used was "Chem-Gro" (HydroGardens, Colorado Springs, Colo.), supplemented with $\mathrm{Ca}\left(\mathrm{NO}_{3}\right)_{2}, \mathrm{CaCl}_{2}, \mathrm{KNO}_{3}$, and $\mathrm{MgSO}_{4}$. All fertilizers were formulated to provide $90 \mathrm{~N}-45 \mathrm{P}-195 \mathrm{~K}$ for stage $1 ; 125 \mathrm{~N}-$ $45 \mathrm{P}-195 \mathrm{~K}$ for stage 2 ; and $165 \mathrm{~N}-45 \mathrm{P}-310 \mathrm{~K}$ for stage 3 (Abbottetal., 1986). Table 2 lists the fertilizer formulations used in all treatments.

\section{Data collection and analysis}

Tissue and media samples were submitted to the North Carolina Dept. of Agriculture

Table 1. Summary of organic substrates and amendments for each growing season, as well as treatment abbreviations.

\begin{tabular}{|c|c|c|c|}
\hline Season & Media & Substrate & Amendments \\
\hline \multirow[t]{6}{*}{$\overline{\mathrm{F} 98}$} & OM1 & $85 \%$ Fafard's Special Organic Mix (P/PB) & \\
\hline & & $15 \%$ Vermicycle worm compost & $6.0 \mathrm{~kg} \cdot \mathrm{m}^{-3}$ dolomitic limestone \\
\hline & & $7.9 \mathrm{~mL} \cdot \mathrm{L}^{-1}$ "Natural Wet" & $1.5 \mathrm{~kg} \cdot \mathrm{m}^{-3}$ blood meal \\
\hline & OM2 & $63 \%$ Scott's 366 Coconut Coir (C/PB) & $1.5 \mathrm{~kg} \cdot \mathrm{m}^{-3}$ bone meal \\
\hline & & $22 \%$ composted pine bark & $1.5 \mathrm{~kg} \cdot \mathrm{m}^{-3}$ potassium sulfate \\
\hline & & $15 \%$ Vermicycle worm compost & \\
\hline \multirow[t]{6}{*}{ S99 } & OM3 & $85 \%$ Fafard's Special Organic Mix (P/PB) & \\
\hline & & $15 \%$ Vermicycle worm compost & $1.79 \mathrm{~kg} \cdot \mathrm{m}^{-3}$ dolomitic limestone \\
\hline & & $7.9 \mathrm{~mL} \cdot \mathrm{L}^{-1}$ "Natural Wet" & $0.89 \mathrm{~kg} \cdot \mathrm{m}^{-3}$ blood meal \\
\hline & OM4 & $63 \%$ Scott's 366 Coconut Coir (C/PB) & $0.89 \mathrm{~kg} \cdot \mathrm{m}^{-3}$ bone meal \\
\hline & & $22 \%$ composted pine bark & $0.89 \mathrm{~kg} \cdot \mathrm{m}^{-3}$ potassium sulfate \\
\hline & & $15 \%$ Vermicycle worm compost & \\
\hline \multirow[t]{5}{*}{ F99 } & OM5 & $85 \%$ Fafard's Special Organic Mix (P/PB) & $0.3 \mathrm{~kg} \cdot \mathrm{m}^{-3}$ elemental sulfur \\
\hline & & $15 \%$ Vermicycle worm compost & $0.89 \mathrm{~kg} \cdot \mathrm{m}^{-3}$ blood meal \\
\hline & & $7.9 \mathrm{~mL} \cdot \mathrm{L}^{-1}$ "Natural Wet" & $0.89 \mathrm{~kg} \cdot \mathrm{m}^{-3}$ bone meal \\
\hline & OM6 & $100 \%$ Fafard's Special Organic Mix (P/PB) & $0.89 \mathrm{~kg} \cdot \mathrm{m}^{-3}$ potassium sulfate \\
\hline & & $7.9 \mathrm{~mL} \cdot \mathrm{L}^{-1}$ "Natural Wet" & \\
\hline
\end{tabular}

(NCDA) to monitor the nutritional status of the plants throughout the growing seasons. Tissue samples were collected by removing the fifth fully expanded leaf from the tops of eight plants from each treatment. Media samples were collected by thoroughly mixing media cores from eight grow bags in each treatment. Samples were collected at three times each season, $\approx 4,8$, and 12 weeks after transplant. Additionally, pour-through medium extractions were conducted using a modified Virginia Tech Extraction Method (VTEM) procedure (Wright, 1986) to provide an immediate, on-site assessment.

The VTEM procedure was modified to accommodate the growth habit of greenhouse tomatoes. All plants were set in saucers on concrete blocks. A hole was made in each saucer. The grow bags were completely saturated by watering from the top. When the solution stopped dripping out of the bottom, the plants were fertigated. Thirty minutes after fertigation, $0.95 \mathrm{~L}$ (1 qt) of water was poured onto the surface of the growing medium. A container was placed under the holes in the saucers to catch the leachate, which was then measured for $\mathrm{pH}$ ( $\mathrm{pHep} \mathrm{pH}$ meter, Hanna Instruments, Woonsocket, R.I.) and electrical conductivity (EC) (DiST WP4 EC meter, Hanna Instruments). Fig. 1 depicts the modified pour-through system.

The rate of plant development was measured by the number of days from seeding to the appearance of the first fully reflexed flower, one of the flowering response criteria described by Picken et al. (1985). Plant development data were collected on the first six clusters of all plants. Harvest yields were determined by the weight per plant of total harvested fruit and No.1 quality fruit only, as well as the percentage of No.1 quality fruit harvested for each greenhouse. Marketable fruit (No. 1) were those that were $>180 \mathrm{~g}$ $(6.35 \mathrm{oz}$.) and without visible defects. Due to incomplete data for the initial harvest of F98, analyses of harvest parameters were based on data collected on all tomatoes from the second through fourth cluster for each greenhouse and growing season.

It was possible to compare OG fertilizers among growing seasons and OG fertilizer $x$ media interactions within seasons using a combined analysis. This analysis was conducted on nutritional status of tissue, media solution $\mathrm{pH}$ and EC, plant development, and harvest yields using GLM(SAS Institute, Cary, N.C.). Within season data means and standard error bars are reported for each system. Error bars reflect within system and within season variation and should not be used to compare the OG and CV systems. Reported effects of OG vs. CV growing systems are qualitative observations.

\section{Results and Discussion}

\section{Pour-through media extraction}

Media solution $\mathrm{pH}$. Media solution $\mathrm{pH}$ values are depicted in Fig. 2. In F98 and S99, there was a significant effect of OG grow- 
Table 2. Fertilizer rates and formulas for all treatments.

\begin{tabular}{|c|c|c|c|}
\hline Fertilizer & Stage 1 & Stage 2 & Stage 3 \\
\hline \multirow[t]{5}{*}{$\overline{\text { Chem-Gro }^{2}}$} & $324.8 \mathrm{~g}(11.46 \mathrm{oz}) 4-18-38$ & $324.8 \mathrm{~g}(11.46 \mathrm{oz}) 4-18-38$ & $324.8 \mathrm{~g}(11.46 \mathrm{oz}) 4-18-38$ \\
\hline & $211.4 \mathrm{~g}(7.46 \mathrm{oz}) \mathrm{Ca}\left(\mathrm{NO}_{3}\right)_{2}$ & $336.6 \mathrm{~g}(11.87 \mathrm{oz}) \mathrm{Ca}\left(\mathrm{NO}_{3}\right)_{2}$ & $352.9 \mathrm{~g}(12.45 \mathrm{oz}) \mathrm{Ca}\left(\mathrm{NO}_{3}\right)_{2}$ \\
\hline & $113.4 \mathrm{~g}(4.00 \mathrm{oz}) \mathrm{CaCl}_{2}$ & $113.4 \mathrm{~g}(4.00 \mathrm{oz}) \mathrm{CaCl}_{2}$ & $58.1 \mathrm{~g}(2.05 \mathrm{oz}) \mathrm{CaCl}_{2}$ \\
\hline & $16.0 \mathrm{~g}(0.56 \mathrm{oz}) \mathrm{KNO}_{3}{ }^{2}$ & $16.0 \mathrm{~g}(0.56 \mathrm{oz}) \mathrm{KNO}_{3}{ }^{2}$ & $235.9 \mathrm{~g}(8.32 \mathrm{oz}) \mathrm{KNO}_{3}$ \\
\hline & $249.5 \mathrm{~g}(8.8 \mathrm{oz}) \mathrm{MgSO}_{4}$ & $249.5 \mathrm{~g}(8.8 \mathrm{oz}) \mathrm{MgSO}_{4}$ & $249.5 \mathrm{~g}(8.8 \mathrm{oz}) \mathrm{MgSO}_{4}$ \\
\hline \multirow[t]{5}{*}{ Earth Juice ${ }^{y}$} & $354 \mathrm{~mL}(12 \mathrm{fl} \mathrm{oz})$ Grow & $473 \mathrm{~mL}(16 \mathrm{fl} \mathrm{oz})$ Grow & $708 \mathrm{~mL}(24 \mathrm{fl} \mathrm{oz})$ Grow \\
\hline & $354 \mathrm{~mL}(12 \mathrm{fl} \mathrm{oz})$ Catalyst & $473 \mathrm{~mL}(16 \mathrm{fl} \mathrm{oz})$ Catalyst & $708 \mathrm{~mL}(24 \mathrm{fl} \mathrm{oz})$ Catalyst \\
\hline & $158 \mathrm{~mL}(5.33 \mathrm{fl} \mathrm{oz})$ Bloom & $118 \mathrm{~mL}$ (4 fl oz) Bloom & $59 \mathrm{~mL}(2 \mathrm{fl} \mathrm{oz})$ Bloom \\
\hline & $118 \mathrm{~mL}(4 \mathrm{fl} \mathrm{oz}) 10 \% \mathrm{~K}$ & $118 \mathrm{~mL}(4 \mathrm{fl} \mathrm{oz}) 10 \% \mathrm{~K}$ & $236 \mathrm{~mL}(8 \mathrm{fl} \mathrm{oz}) 10 \% \mathrm{~K}$ \\
\hline & --- & $118 \mathrm{~mL}$ (4 fl oz) Microburst & $118 \mathrm{~mL}$ (4 fl oz) Microburst \\
\hline \multirow[t]{3}{*}{ Magna Gro Recipes ${ }^{x}$} & $1 \mathrm{~L}(34 \mathrm{fl} \mathrm{oz}) \mathrm{HBM}^{\mathrm{w}}$ & $1 \mathrm{~L}(34 \mathrm{fl} \mathrm{oz}) \mathrm{HBM}$ & $1 \mathrm{~L}(34 \mathrm{fl} \mathrm{oz}) \mathrm{HBM}$ \\
\hline & $7 \mathrm{~mL}(0.25 \mathrm{fl} \mathrm{oz}) 19 \% \mathrm{~N}$ & $79 \mathrm{~mL}(2.67 \mathrm{fl} \mathrm{oz}) 19 \% \mathrm{~N}$ & $236 \mathrm{~mL}(8 \mathrm{fl} \mathrm{oz}) 19 \% \mathrm{~N}$ \\
\hline & $59 \mathrm{~mL}(2 \mathrm{fl} \mathrm{oz}) 9 \% \mathrm{~K}_{2} \mathrm{O}$ & $59 \mathrm{~mL}(2 \mathrm{fl} \mathrm{oz}) 9 \% \mathrm{~K}_{2} \mathrm{O}$ & $473 \mathrm{~mL}(16 \mathrm{fl} \mathrm{oz}) 9 \% \mathrm{~K}_{2} \mathrm{O}$ \\
\hline
\end{tabular}

${ }^{\mathrm{z} F o r} 1 \mathrm{gal}$ of stock injected at a rate of 1:100.

${ }^{y}$ For $1 \mathrm{gal}$ of stock injected at a rate of 1:20.

${ }^{x}$ For 1 gal of stock injected at a rate of 1:70.

${ }^{\text {w} H y d r o p o n i c ~ B a s e ~ M i x . ~}$

ing media on the media $\mathrm{pH}(P=0.0002)$. In both seasons, the media containing the $\mathrm{P} / \mathrm{PB}$ substrate resulted in higher $\mathrm{pH}$ than the media containing $\mathrm{C} / \mathrm{PB}$, even though $\mathrm{C} / \mathrm{PB}$ has a near-neutral $\mathrm{pH}$ and peat moss and pine bark blends are generally acidic. However, the commercial mix used for the $\mathrm{P} / \mathrm{PB}$ substrate had been $\mathrm{pH}$ corrected by the manufacturer which led to a higher $\mathrm{pH}$ in these media than in the $\mathrm{C} / \mathrm{PB}$ media. In F99, media containing worm compost had lower $\mathrm{pH}$ than media without compost. There were no significant differences between the two OG fertilizers on growing media $\mathrm{pH}(P=0.6564)$.

In the $\mathrm{CV}$ system, medium $\mathrm{pH}$ was above the optimal range in F98. In S99 it was within range and in $\mathrm{F} 99$, $\mathrm{pH}$ was very low, ranging from 4.8-5.2 (Fig. 2). In an effort to keep the $\mathrm{OG}$ and $\mathrm{CV}$ growing systems as similar as possible, media were amended with the same amounts of dolomitic limestone for all treatments. Since media $\mathrm{pH}$ was detrimentally high in the OG treatments in F98, the amount of dolomitic limestone amendment was reduced
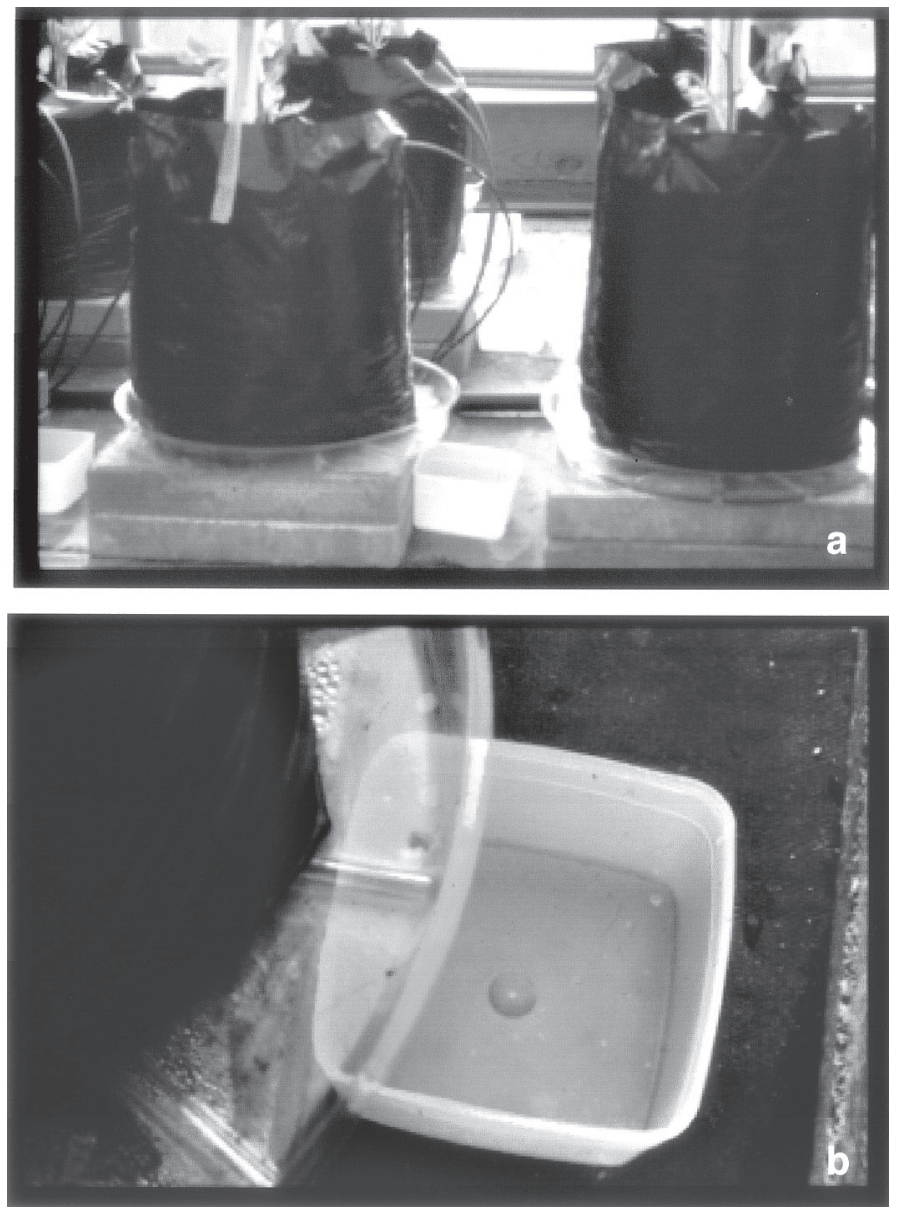

Fig. 1. (a) Modified Virginia Tech Extraction Method (VTEM) pour-through medium extraction systemside view. (b) Modified VTEM pour-through system - tray and catch cup.

in S99 and omitted in F99. Since CV utilized acidic peat-based media and fertilizers, the omission of limestone in F99 resulted in excessively low $\mathrm{pH}$ for this system.

In all growing seasons, the media solution $\mathrm{pH}$ was higher in OG than CV (Fig. 2). This result was considered to be unusual since organic fertilizers tend to contain a higher percentage of ammoniacal-N $\left(\mathrm{NH}_{4}^{+}-\mathrm{N}\right)$ than conventional fertilizers. As plants take up $\mathrm{NH}_{4}^{+}-\mathrm{N}$, they exude hydrogen $\left(\mathrm{H}^{+}\right)$ions to maintain an electrical gradient within the roots. Additionally, the microbial process of nitrification, in which $\mathrm{NH}_{4}^{+}$is converted to nitrate $\left(\mathrm{NO}_{3}{ }^{-}\right)$, results in the release of $\mathrm{H}^{+}$ions. The abundance of $\mathrm{H}^{+}$in the rhizosphere was expected to lower the $\mathrm{pH}$. Other researchers and growers who have worked with OG systems have also noticed increased substrate $\mathrm{pH}$ when using carbon-based (P.V. Nelson, unpublished data) or organic (Biernbaum, 1998, personal communication) fertilizers. Soil $\mathrm{H}^{+}$binds with ammonia $\left(\mathrm{NH}_{3}\right)$ released from organic matter and forms ammonium ions $\left(\mathrm{NH}_{4}^{+}\right)$. If this were the case, then organic substances could be less acidifying than inorganic substances with equivalent reduced $\mathrm{N}$ (Nelson, 2000).

From these results, it seems possible that substrate $\mathrm{pH}$ management is more critical for $\mathrm{CV}$ than $\mathrm{OG}$ systems. OG substrate $\mathrm{pH}$ was very high in S99 when the greatest harvest yields were produced. It was also high in F98 when low yields resulted. Interestingly, in F99, OG substrate was within the recommended range, but this season also resulted in low yields. CV harvest yields responded to substrate $\mathrm{pH}$ in accordance with generally understood $\mathrm{pH}$ management principles. When $\mathrm{CV}$ substrate $\mathrm{pH}$ levels were outside the range for optimum plant development (high in F98, low in F99), CV yields were correspondingly low. Likewise, CV yields were the highest when $\mathrm{pH}$ was within the optimal range (S99), Conversely, in this growing season, when OG $\mathrm{pH}$ was the highest, three of the four OG treatments produced greater harvest yields than $\mathrm{CV}$, which were the same as those for the fourth OG treatment.

Media solution EC. At $\approx 4$ weeks (Fig. 3), EC was higher in $\mathrm{OG}$ than $\mathrm{CV}$ from transplanting to the 4-week sampling in all seasons. After that 

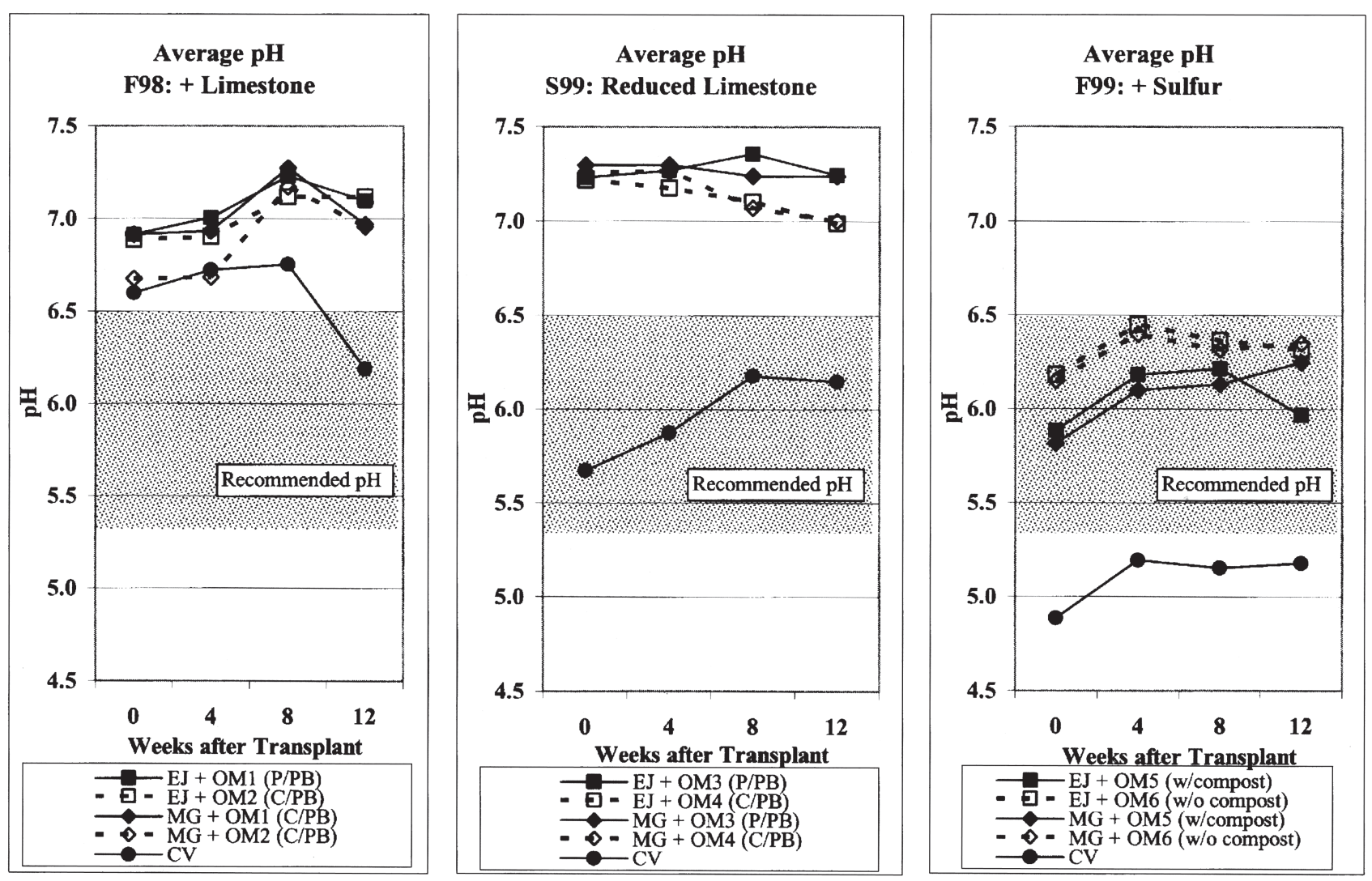

Fig. 2. Average media solution $\mathrm{pH}$ measured by a modified Virginia Tech Extraction Method (VTEM) pour-through media extraction procedure. EJ = Earth Juice; MG = Magna Gro; CV = conventional; and OM1, OM2, OM3, OM4, OM5, or OM6 = Organic Growing Medium 1, 2, 3, 4, 5, or 6.

period, EC levels were comparable among all treatments for the remainder of each growing season. It seems that the differences were due to the OG nutrient amendments that were added to the substrates. Neither OG fertilizers nor OG media resulted in significant differences in media solution EC $(P=0.0603$ and $P=$ 0.5325 , respectively). Additionally, there were no significant fertilizer $\times$ media interactions $(P=0.8488)$

\section{Nutritional status}

Table 3 lists the treatment means and analysis of variance (ANOVA) results of tissue analysis on samples of the fifth fully expanded leaf from the tops of eight plants per treatment. Data for $\mathrm{N}, \mathrm{P}, \mathrm{K}, \mathrm{Ca}$, and $\mathrm{Mg}$ from the middle of each growing season are reported. There were significant differences among growing seasons on levels of all elements analyzed except $\mathrm{Ca}$ and $\mathrm{Mg}$. In F99, tissue levels of $\mathrm{N}$, P, and $\mathrm{K}$ were significantly higher than those from other seasons. In F99, OG media $\mathrm{pH}$ was maintained within the optimal range for tomato plant growth of 5.5-6.8 (Maynard and Hochmuth, 1997). This is the range in which macronutrients are most readily available for plant uptake. In the previous growing seasons, OG media $\mathrm{pH}$ was above this range, causing most macronutrients to be less available for uptake (Maynard and Hochmuth, 1997).

Effects of organic growing media. There were no significant effects of OG growing media on the tissue levels of any of the nutrients except Mg. In F98 and S99, plants grown in the media containing $\mathrm{C} / \mathrm{PB}$ had lower levels of $\mathrm{Mg}$ than plants grown in the media containing the $\mathrm{P} / \mathrm{PB}$ substrate. In these two growing seasons, both substrates were amended with equal amounts of dolomitic limestone. However, the media containing the commercial mix used for the $\mathrm{P} / \mathrm{PB}$ substrate already contained dolomitic limestone to adjust for $\mathrm{pH}$. Dolomitic limestone is a good source of $\mathrm{Mg}$ so it is probable that the difference in tissue levels of $\mathrm{Mg}$ were a result of the additional limestone in the growing media.

Effects of organic fertilizers. OG fertilizers had no significant effects on the nutritional status of the leaf tissue. Likewise, there were no significant $\mathrm{OG}$ fertilizer $\times$ media interactions.

Nitrogen (Table 3). In F98, plants that received MG had generally lower levels of $\mathrm{N}$ in leaf tissue than plants fertilized with $\mathrm{EJ}$ or $\mathrm{CV}$. In F98 and S99, there was a trend for plants in the OG system to have the highest levels of $\mathrm{N}$ in tissue at the mid-season sampling (data not shown). It is possible that by then, nitrifying bacteria had converted some of the $\mathrm{NH}_{4}^{+}-\mathrm{N}$ that is prevalent in $\mathrm{OG}$ nutrients into the more readily useable $\mathrm{NO}_{3}^{-}-\mathrm{N}$. During these periods, plants in the OG system had tissue levels of $\mathrm{N}$ that approximated those recommended by the NCDA. Plants grown in the CV system consistently had $\mathrm{N}$ levels in tissue that were equivalent to recommended levels.

Phosphorous (Table 3). There was little difference among treatments in the levels of $\mathrm{P}$ in leaf tissue. Generally, these levels were higher than recommended amounts. Media $\mathrm{pH}$ was near-neutral in both the OG and CV systems in F98 and S99 (Fig. 2). This condition allows P to be more available to plants than it is when $\mathrm{pH}$ is in the more acidic range that is optimal for the growth of most plants (Maynard and Hochmuth, 1997).

Potassium (Table 3). Tissue levels of K were greater in CV than OG for F98 and S99. In F99, $\mathrm{K}$ levels were similar in all treatments. Leaf tissue levels of $\mathrm{K}$ were lower than the recommended levels in all treatments and for all growing seasons. This result was unexpected since this was one of the nutrients upon which calculations for all the fertilizer formulations were based. It is possible that there was competition with other cations such as $\mathrm{Ca}$ for binding sites in the growing media, and $\mathrm{K}$ was leached out.

Calcium (Table 3). Tissue levels of Ca were higher in $\mathrm{OG}$ treatments containing the $\mathrm{P} / \mathrm{PB}$ substrate than those using the $\mathrm{C} / \mathrm{PB}$ substrate. This was most likely a reflection of the amount of dolomitic limestone, a source of $\mathrm{Ca}$, which was in the growing medium (see discussion of $\mathrm{Mg}$ above). Levels of Ca were generally lower in the plants grown in the OG as opposed to the CV systems. In all cases, tissue Ca was within the range of recommended values.

\section{Plant development}

Effects of organic fertilizers and media. Table 4 lists data means for the OG and CV 

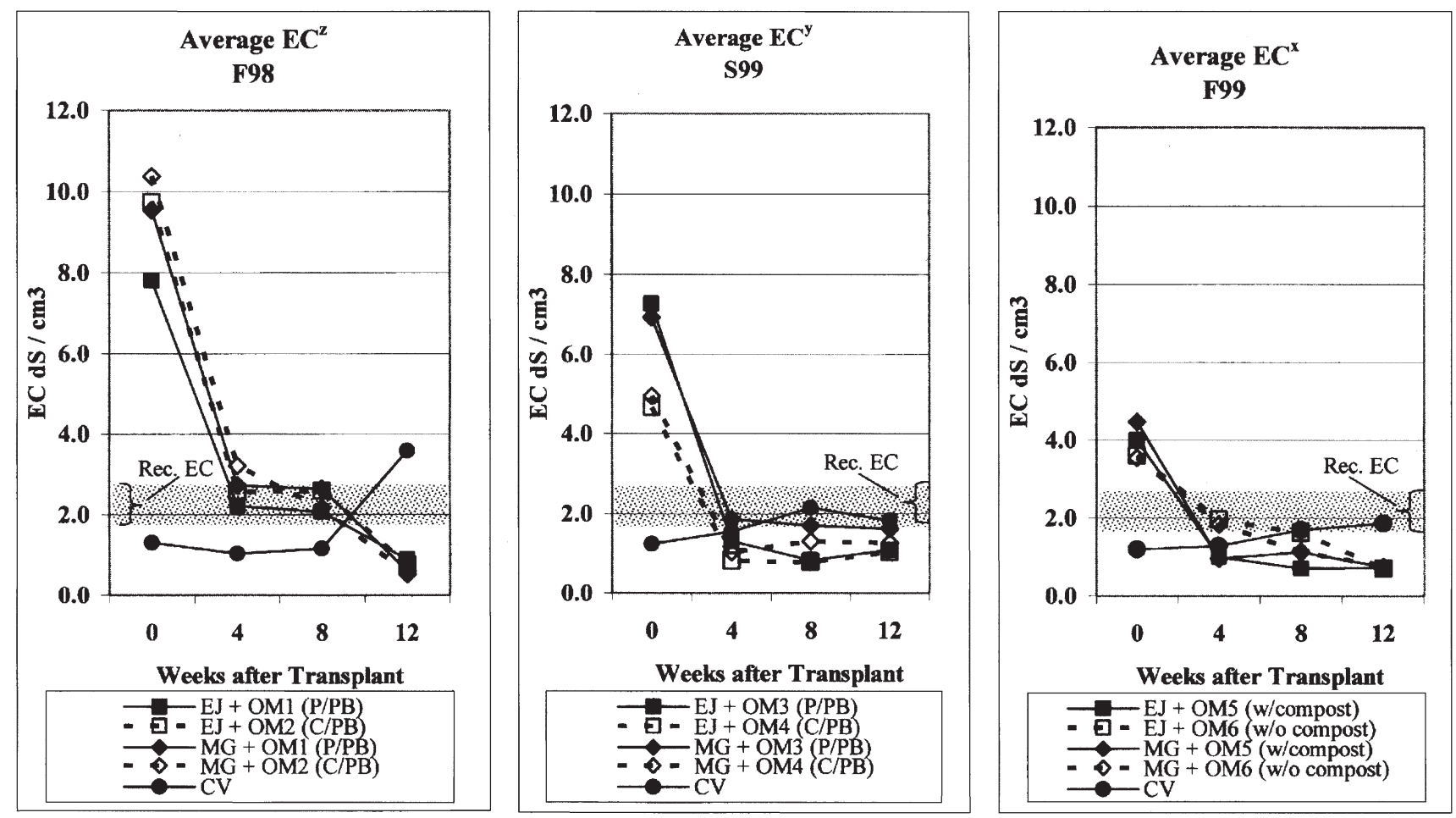

Fig. 3. Average media solution EC measured by a modified Virginia Tech Extraction Method (VTEM) pour-through media extraction procedure. EJ = Earth Juice; $\mathrm{MG}$ = Magna Gro; $\mathrm{CV}$ = conventional; and OM1, OM2, OM3, OM4, OM5, or OM6 = Organic Growing Medium 1, 2, 3, 4, 5, or 6.

treatments, as well as OG treatment ANOVA results for the number of days from seeding to the first fully reflexed flower on each of the first six clusters. There were no significant OG fertilizer or medium effects. Likewise, the $\mathrm{OG}$ fertilizer $\times$ media interactions were nonsignificant.

System effects. Differences were negligible between $\mathrm{OG}$ and $\mathrm{CV}$ systems on the number of days from seeding to flower (Table 4). In F98, CV plants set flowers on the first two clusters

Table 3. Organic (OG) and conventional (CV) treatment means, and $\mathrm{OG}$ treatment analysis of variance (ANOVA) results of the North Carolina Dept. of Agriculture (NCDA) tissue analysis of macronutrients from the mid-season sampling for each growing season. NCDA recommended values are included.

\begin{tabular}{llccccc}
\hline & & \multicolumn{5}{c}{ Nutrients in leaves (\%) } \\
\cline { 3 - 6 } Season & Treatment & $\mathrm{N}$ & $\mathrm{P}$ & $\mathrm{K}$ & $\mathrm{Ca}$ & $\mathrm{Mg}$ \\
\hline F98 & EJ1 (P/PB) & 4.655 & 0.520 & 3.455 & 1.685 & 0.390 \\
& EJ2 (C/PB) & 4.855 & 0.530 & 2.955 & 1.455 & 0.365 \\
& MG1 (P/PB) & 3.955 & 0.635 & 2.485 & 1.845 & 0.480 \\
& MG2 (C/PB) & 3.765 & 0.585 & 2.305 & 1.580 & 0.350 \\
S99 & CV & 4.890 & 0.468 & 3.970 & 1.575 & 0.415 \\
& EJ3 (P/PB) & 4.010 & 0.515 & 3.245 & 1.700 & 0.425 \\
& EJ4 (C/PB) & 4.850 & 0.600 & 3.510 & 1.825 & 0.370 \\
& MG3 (P/PB) & 4.895 & 0.655 & 3.580 & 1.340 & 0.370 \\
F99 & MG4 (C/PB) & 5.185 & 0.655 & 3.440 & 1.175 & 0.305 \\
& CV & 4.973 & 0.598 & 4.533 & 2.278 & 0.433 \\
& EJ5 (w/compost) & 5.480 & 0.940 & 5.005 & 1.865 & 0.510 \\
& EJ6 (w/o compost) & 5.630 & 0.735 & 5.560 & 1.420 & 0.555 \\
NCDA Rec. & MG5 (w/compost) & 6.440 & 0.880 & 6.010 & 1.790 & 0.485 \\
& MG6 (w/o compost) & 6.780 & 1.015 & 5.820 & 1.380 & 0.580 \\
Season (S) & CV & 6.368 & 0.975 & 5.755 & 2.398 & 0.530 \\
Fertilizer (F) & $4.0-5.5$ & $0.3-1.0$ & 4.7 & 1.5 & 0.500 \\
S $\times$ F & & ANOVA P-values & & & & \\
Media (season) & & $<0.0001$ & 0.0037 & $<0.0001$ & 0.0660 & 0.7695 \\
F $\times$ Media (season) & & 0.2569 & 0.1416 & 0.9331 & 0.2334 & 0.9731 \\
& & 0.0932 & 0.6513 & 0.3227 & 0.9714 & 0.7173 \\
& & 0.9798 & 0.8527 & 0.9855 & 0.3277 & 0.0197 \\
& & 0.9997 & 0.4611 & 0.9984 & 0.9111 & 0.9582 \\
\hline
\end{tabular}

\section{Harvest yields}

this trend was reversed by the time flowers were set on the last two clusters. In S99, OG plants set flowers on the second and third clusters sooner than conventionally grown plants, but again, this trend was reversed for the sixth cluster. In F99, CV and OG plants set flowers on the first two clusters in the same amount of time, however, for each successive cluster, the $\mathrm{CV}$ plants produced flowers earlier than the OG plants.

Effects of organic fertilizers. Organic fertilizers did not significantly affect total yield $(P=0.3335)$, yield of No.1 fruit $(P=0.3046)$, or percentage of No. 1 fruit $(P=0.3574)$ according to the ANOVA (SAS Institute, Cary, N.C.) (Fig. 4). Within seasons, there were no significant differences between OG fertilizers for any of the harvest parameters measured. However, higher total yields and yields of No. 1 fruit from plants grown with EJ than with MG were observed in F98, while higher yields from MG were observed in S99 and F99 (Fig. 4). This could be attributed to the difficulty in delivering soluble organic fertilizers due to repeated clogging of the fertigation emitters. When emitters became clogged, plants were not receiving an adequate supply of nutrients. Analysis of leaf tissue samples revealed lower amounts of $\mathrm{N}$ in plants fertilized with MG in F98 and EJ in S99 (Table 3). Later in each season, the problem of clogging was partially overcome by keeping the concentrate stirred, flushing out the irrigation lines weekly, and checking emitters frequently for clogging. Other strategies to deal with the high particulate content could include using emitters with high flow rates, e.g., $7.6 \mathrm{~L} \cdot \mathrm{h}^{-1}$ $(2.0 \mathrm{gal} / \mathrm{h})$ instead of $1.89 \mathrm{~L} \cdot \mathrm{h}^{-1}(0.5 \mathrm{gal} / \mathrm{h})$, and adjusting dilution ratios in the injectors to feed a less concentrated fertilizer solution.

Effects of organic media. Differences in total yield, yield of No. 1 fruit, and percentage of No. 1 fruit were nonsignificant $(P=0.7404$, $P=0.4327$, and $P=0.7198$, respectively) among media treatments within any growing season. There were no significant fertilizer $x$ 
Table 4. Organic (OG) and conventional $(\mathrm{CV})$ treatment means, and $\mathrm{OG}$ treatment analysis of variance (ANOVA) results from the number of days from seeding to the first, fully reflexed flower on the first through the sixth clusters for each growing season.

\begin{tabular}{|c|c|c|c|c|c|c|c|}
\hline \multirow{2}{*}{ Season } & \multirow[b]{2}{*}{ Treatment } & \multicolumn{6}{|c|}{ Cluster number ${ }^{z}$} \\
\hline & & 1 & 2 & 3 & 4 & 5 & 6 \\
\hline \multirow[t]{5}{*}{ F98 } & EJ1 & 47 & 55 & 61 & 66 & 72 & 80 \\
\hline & $\mathrm{EJ} 2$ & 46 & 55 & 60 & 65 & 71 & 82 \\
\hline & MG1 & 45 & 54 & 61 & 66 & 71 & 80 \\
\hline & MG2 & 44 & 54 & 61 & 66 & 72 & 80 \\
\hline & $\mathrm{CV}$ & 44 & 52 & 61 & 66 & 73 & 83 \\
\hline \multirow[t]{5}{*}{ S99 } & EJ3 & 59 & 67 & 73 & 80 & 87 & 98 \\
\hline & EJ4 & 60 & 67 & 73 & 81 & 89 & 99 \\
\hline & MG3 & 60 & 68 & 74 & 81 & 89 & 97 \\
\hline & MG4 & 60 & 68 & 74 & 82 & 89 & 97 \\
\hline & $\mathrm{CV}$ & 60 & 69 & 76 & 81 & 89 & 93 \\
\hline \multirow[t]{5}{*}{ F99 } & EJ5 & 51 & 61 & 69 & 77 & 84 & 92 \\
\hline & EJ6 & 49 & 61 & 69 & 78 & 85 & 92 \\
\hline & MG5 & 49 & 59 & 68 & 76 & 83 & 90 \\
\hline & MG6 & 51 & 62 & 71 & 79 & 86 & 93 \\
\hline & $\mathrm{CV}$ & 51 & 61 & 68 & 75 & 82 & 90 \\
\hline \multicolumn{8}{|c|}{ ANOVA P-values } \\
\hline \multicolumn{2}{|c|}{ Season $(\mathrm{S})$} & $<0.0001$ & $<0.0001$ & $<0.0001$ & $<0.0001$ & $<0.0001$ & $<0.0001$ \\
\hline \multicolumn{2}{|c|}{ Fertilizer (F) } & 0.6102 & 0.6327 & 0.2999 & 0.3705 & 0.5967 & 0.0778 \\
\hline \multicolumn{2}{|c|}{$\mathrm{S} \times \mathrm{F}$} & 0.1384 & 0.4918 & 0.6772 & 0.6698 & 0.6400 & 0.8772 \\
\hline \multicolumn{2}{|c|}{ Media (season) } & 0.6911 & 0.4645 & 0.2668 & 0.4282 & 0.3636 & 0.6406 \\
\hline \multicolumn{2}{|c|}{$\mathrm{F} \times \mathrm{Media}$ (season) } & 0.1850 & 0.4880 & 0.6104 & 0.7832 & 0.7974 & 0.6420 \\
\hline
\end{tabular}

${ }^{2}$ Clusters are numbered in order of appearance on the plant (i.e., from the growing medium to the top of the plant.
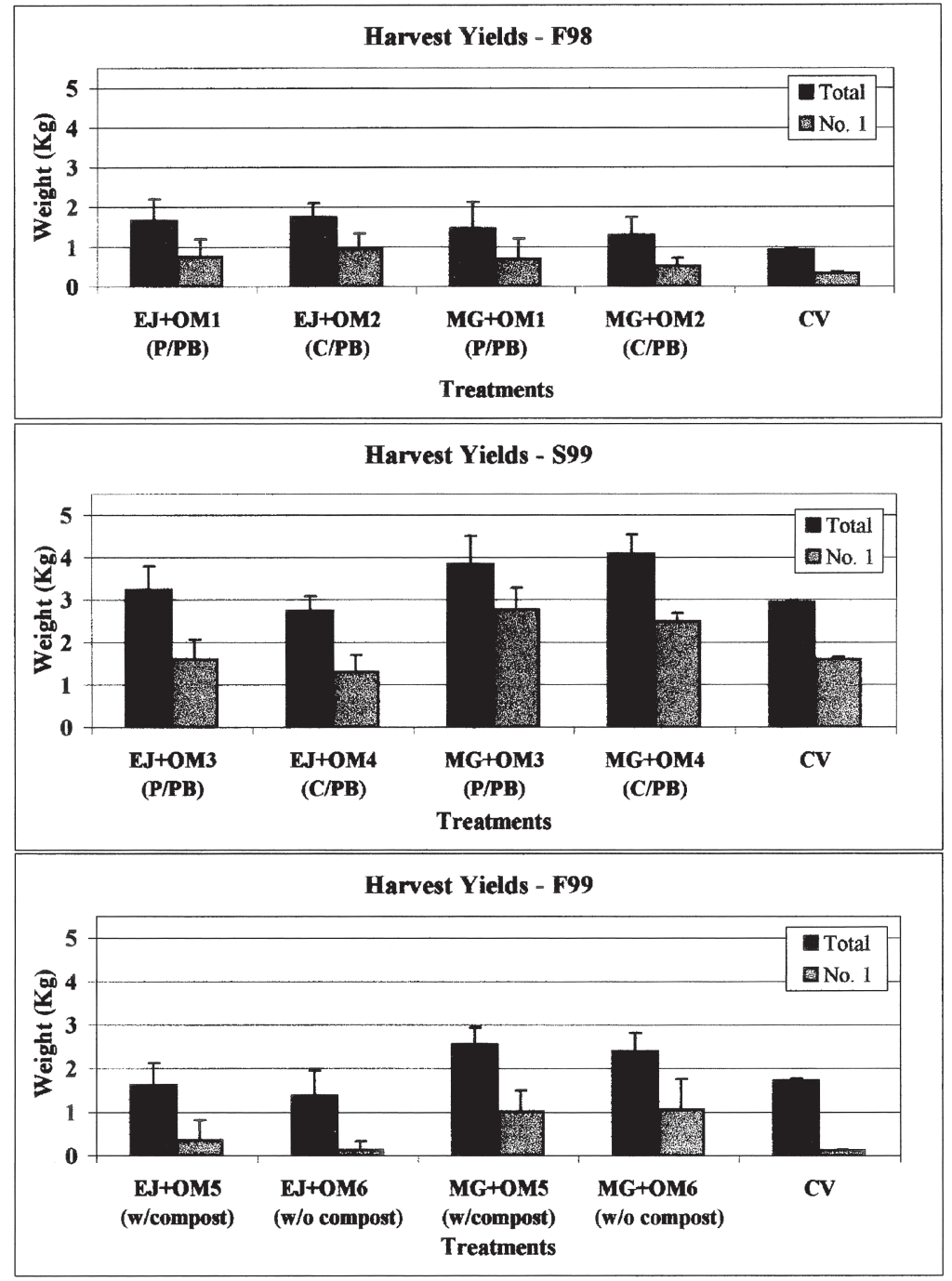

Fig. 4. Harvest yields of total fruit and No. 1 fruit. Total weight per plant $(\mathrm{kg})$ from the second through fourth clusters. EJ = Earth Juice; MG = Magna Gro; and CV = conventional; OM1, OM2, OM3, OM4, OM5, or OM6 = Organic Growing Medium 1, 2, 3, 4, 5, or 6 . media interactions for total yield $(P=0.3166)$, yield of No. 1 fruit $(P=0.6665)$, or percentage of No. 1 fruit $(P=0.7898)$. Although the differences were nonsignificant, it was observed that the organic media containing the $\mathrm{P} / \mathrm{PB}$ substrate tended to produce higher total yields and yields of No. 1 fruit than media containing the $\mathrm{C} / \mathrm{PB}$ substrate in F98 and S99 (Fig. 4).

Systems effects. Figs. 4 and 5 are based on the average weight $(\mathrm{kg})$ per plant for all treatments. In F98, total yields as well as yields of No. 1 fruit were higher in all OG treatments than in CV. The same was true in S99 with the exception that EJ plus $\mathrm{C} / \mathrm{PB}$ produced slightly lower total and No. 1 yields than CV. However, the percentage of No. 1 fruit was comparable in both systems for these two growing seasons.

Although total harvest yields were similar between OG and CV in F99, the percentage of No. 1 fruit was much lower in CV than OG. Likewise, the yield of No. 1 fruit for this season was higher in three of the four OG treatments than $\mathrm{CV}$, which produced the same results as those from the EJ/without compost treatment. In this growing season, most of the $\mathrm{CV}$ fruit were very small. This phenomenon was most likely due to the exceptionally low substrate $\mathrm{pH}$ in this growing system.

\section{Conclusions}

In this study, there were no significant differences among the OG treatments for any of the criteria used to measure plant growth and development. The variations in the nutritional status of the plants that did occur were largely attributed to either the actual amounts of nutrients added, in the case of $\mathrm{Ca}$ and $\mathrm{Mg}$, or the $\mathrm{pH}$ level of the media. These data suggest that media $\mathrm{pH}$ plays a greater role in nutrient availability, and consequently plant growth and harvest yields, in CV systems than it does in OG systems.

EC measurements were exceptionally high in the OG system for about the first 4 weeks after transplant, followed by EC levels in the OG system that were comparable to those in the CV system for the remainder of each growing season. The OG media were mixed within 1 week of transplanting. These findings suggest that OG media might be more stable if they were allowed to stand for $\approx 4$ weeks after mixing in order to achieve equilibrium.

As with any system, growers need to modify standard practices to fit their own situation. There were only a few management practices that differed between the OG and CV systems. In the OG system, it was necessary to mix soluble fertilizers on a weekly basis and to keep the fertilizer stock tank agitated. It was also beneficial to flush the irrigation lines weekly with water, and to check the emitters regularly.

Since organic and conventional growing systems are inherently different, it was impossible to control experiments for all but one variable. Nevertheless, when the growing systems are considered as a whole, our experience suggests that greenhouse tomatoes produced organically are comparable to those produced 

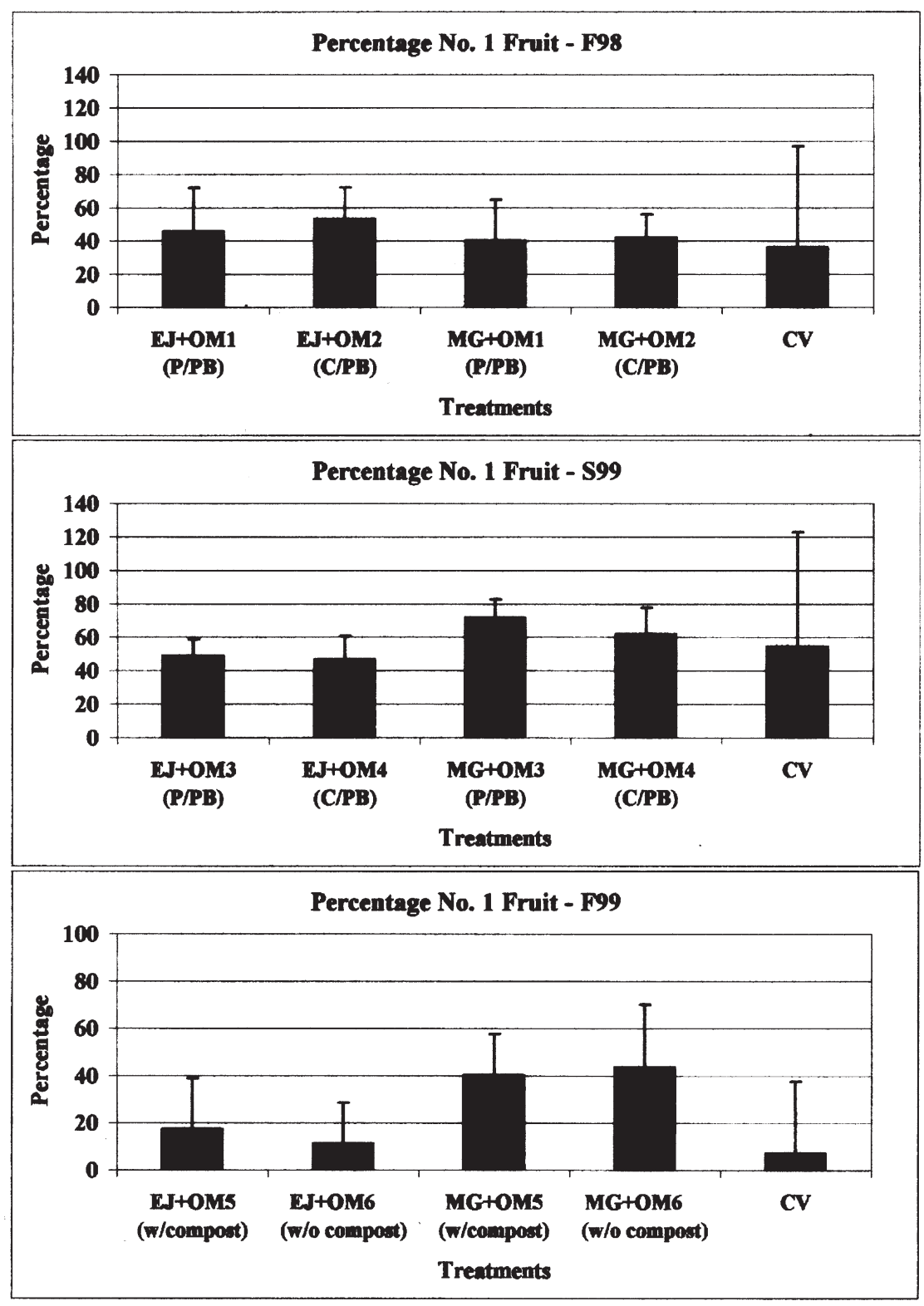

Fig. 5. Percentage of No. 1 fruit from the second through fourth clusters. EJ = Earth Juice; $M G=$ Magna Gro; and CV = conventional; OM1, OM2, OM3, OM4, OM5, or OM6 = Organic Growing Medium $1,2,3,4,5$, or 6 .

conventionally in regards to nutritional status, plant development, and harvest yields.

\section{Literature Cited}

Abbott, J.D., M.M. Peet, D.H. Willits, and R.E. Gough. 1985. Water management of greenhouse tomatoes. HortScience 20(4):688-690.

Carpenter, T.D. 1982. Analyzing and managing nutrition of vegetables grown in upright polyethylene bags. J. Plant Nutr. 5:1083-1089.

Dimitri, C. and N.J. Richman. 2000. Organic Foods: Niche marketers venture into the mainstream. p. 11-15. Agr. Outlook. AGO-272.
Drews, M. and B. Rennert. 1992. Investigations on the combination of intensive fish farming and NFT procedure in growing cucumber and tomatoes in greenhouses. Gartenbauwissenschaft 57:44-48.

Estes, E., T. Kleese, L. Lauffer, D. Treadwell, and R. Burton. 1999. An overview of the North Carolina organic industry. ARE Rpt. No. 17, N.C. Agr. Res. Serv., N.C. State Univ., Raleigh.

Flynn, R.P. C.W. Wood, and E.A. Guertal. 1995. Lettuce response to composted broiler litter as a potting substrate component. J. Amer. Soc. Hort. Sci. 120:964-970.

Greene, C. 2000. U.S. Organic agriculture gaining ground. Agr. Outlook, Apr. 2000, ERSAO-270. Can be accessed as pdf. <www.usda.gov/publications/agoutlook/apr2000/>.

Greene, C.R. 2001. U.S. organic farming emerges in the 1990s: Adoption of certified systems. Agr. Info. Bul.: ERSAIB770.

Greene, C., C. Dimitri, and N. Richman. 2001. Organic marketing features fresh foods and direct exchange, p. 31-37. Food Rev. No. 24-1.

Grubinger, V.P. 1999. Sustainable vegetable production from start-up to market. NRAES-104. NRAES, Ithaca, N.Y. p. 229.

Ingram, E.R. and M. Alms. 1999. Compost tea manual 1.1. Soil Foodweb. Growing Solution, Eugene, Ore. Copies obtainable from Organic Farming Res. Fdn., Santa Cruz, Calif. telephone 831-426-6670.

Kraus, H.T., R.L. Mikkelsen, and S.L Warren. 2000. Container substrate temperatures affect mineralization of composts. HortScience $35: 16-18$.

Kraus, H.T. and S.L. Warren. 2000. Performance of turkey litter compost as a slow-release fertilizer in containerized plant production. HortScience 35:19-21.

Lampkin, Nicolas. 1990. Organic farming, p. 1. Ipswich Farming Press, Bridlington, U.K.

Maynard, D.N. and G.J. Hochmuth. 1997. Knott's handbook for vegetable growers. 4th ed. Wiley, New York. p. 136, 138-139.

Smith, M. 1994. The real dirt. Farmers tell about organic and low-input practices in the northeast, p 116. Northeast Organic Farming Assn., Burlington, Vt.

Tyler, H.H., S.L. Warren, T.E. Bilderback, and W.C. Fonteno. 1993a. Composted turkey litter. I. Effect on chemical and physical properties of a pine bark substrate. J. Environ. Hort. 11:131-136

Tyler, H.H., S.L. Warren, T.E. Bilderback, and K.B. Perry. 1993b. Composted turkey litter. II. Effect on plant growth. J. Environ. Hort. $11: 137-141$

Uri, N.D. 1999. Agriculture and the environment. p.1. Nova Science Publishers. Commack, N.Y.

Wright, R.D. 1986. The pour-through nutrient extraction method procedure. HortScience $21: 227-229$ 